TAPROBANICA, ISSN 1800-427X. April, 2013. Vol. 05, No. 01: 1-5.

(C) Taprobanica Private Limited, 146, Kendalanda, Homagama, Sri Lanka.

www.taprobanica.org

\title{
EDITORIAL
}

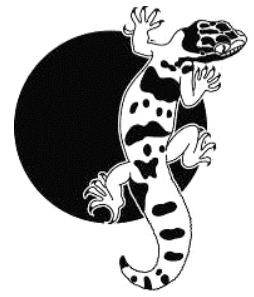

\section{Wildlife Poaching Increasing}

After decades of endangered species protection and conservation success, poachers are staging a come-back. Most people in Europe and North America just don't believe that rhinoceros horn, monkey meat, tiger penis or bear bile have any curative or health properties, but millions of people in East Asia and Southeast Asia believe otherwise (Alves et al., 2010). This cultural predilection is driving extinction. As repugnant as it is to those living outside the range of non-human primates, monkey meat provides a much-needed source of protein in some circumstances-but not enough to justify their extinction. There is no such nutritional excuse for poaching tigers, bears or rhinoceros. Since the start of 2008, at least 1800 white rhinoceroses and a few of the rarer black rhinoceroses have been killed in South Africa for their horns, most smuggled into Vietnam and China (Humane Society International, 2013; Stop Rhino Poaching Now, 2013; World Wildlife Fund, 2012).

\section{White rhinoceros killed in South Africa}

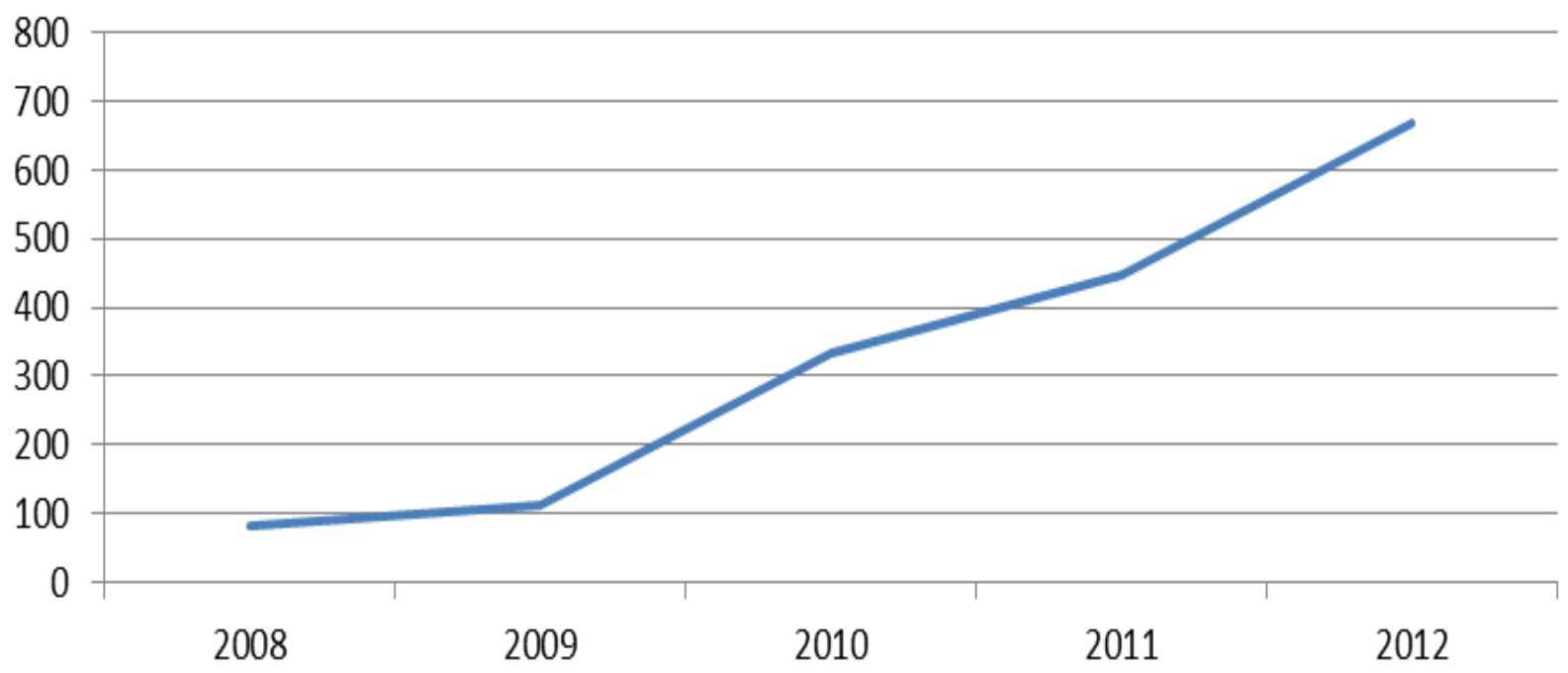

Figure 1: Known cases of poaching of white rhinoceros in South Africa since 2008

In April this year, Mozambique authorities reported that the last 15 of a once-thriving population of white rhinoceros had been killed, extirpating them from that country (Conway-Smith, 2013). The Northern White Rhinoceros, recently recognized as a distinct species (Groves et al., 2010), teeters on the brink of extinction with fewer than 20 individuals left, all of them in the Democratic Republic of Congo, where poachers operate with seeming impunity (Groves et al., 2010). The Indian one-horned rhinoceros, rescued from extinction since 1975 and now numbering about 3000 (World Wildlife Fund Global, 2013), is under heightened threat from poachers, with at least 21 killed last year and already 15 this year (Hussain, 2013). The Sumatran, or two-horned rhinoceros is down to fewer than 400 individuals in Indonesia and Malaysia, perhaps a dozen on Borneo, and is probably extirpated from Myanmar. The Javan, or lesser one-horned rhinoceros, has only a few dozen individuals left on Java; its Indian subspecies went extinct in 1925; and in 2010, the very last Vietnamese rhinoceros, another subspecies of the Javan rhino, was killed for its meagre horn (Brook et al., 2011). Who, in good conscience, would condone killing the last member of its species (or in this case, subspecies)? 
Rhinoceros horns are made of keratin, the same protein that makes human hair and fingernails.

It doesn't cure anything. Restaurants and pharmacies in many Asian countries, including China, Cambodia, Japan Korea, and Vietnam, serve and sell endangered wildlife, and the rarer the better: it is a sign of wealth. China is a major importer of illegally poached and smuggled wildlife because its rapid economic development has created huge demand for these luxury, illicit foods and medicines. The cultural predilection for exotic foods follows Chinese immigrants to Canada, as shown by a current furor over shark fin soup; many Canadian towns and a few cities have banned this delicacy. That it is a cause célèbre among conservationists has not prevented politicians from defiantly sitting down to dine on shark fin soup in Chinese neighbourhoods in Toronto and Vancouver. Every large predator-leopards, lions, bears - is poached for international trade. The Wildlife Protection Society of India documented 1,067 tiger deaths due to poaching since 1994 and considered that these "represent only a fraction of the actual poaching and trade [to China] in tiger parts in India." In Canada, bears are regularly poached for their bile for export to China.

On a 2007 jungle hike in Malaysia in search of monkeys for a research project, I came across a camp where Orang Asli people were smoking primate meat on almost an industrial scale. The Orang Asli are indigenous people not related to the dominant Malays, many of whom make a living hunting, as do other groups throughout Indonesia and Malaysia. These two countries are thought to be significant sources of illegal wildlife to trade to China (Meijaard \& Sheil, 2008; Nijman, 2005; Nijman \& Meijaard, 2008; Wich et al., 2008). Well-organized syndicates smuggle animal products through Myanmar, Laos and Vietnam to China's Yunnan and Guangxi provinces. While I was in Kuala Lumpur, the government announced its first endangered species protection law to implement the Convention on International Trade in Endangered Species (CITES) - a treaty that Malaysia had signed in 1977. Better late than never, I suppose.

In Vietnam, the Muong, Hmong and other indigenous "hill tribes" specialize in hunting wildlife for meat and to sell. Likewise, in Yunnan, China, ethnic minorities such as the $\mathrm{Nu}$ and Lisu use crossbows and snares to supplement their hill crops with wildlife as a source of food and market income (Goodman, 2009). This spring, on the edge of the Tibetan Plateau in Yunnan, I noticed men wearing hats made of red panda fur, a common cultural style (Goodman, 2009). Among the Aini ethnic group of southern Yunnan, a successful hunter of gibbons was regarded as the standard of a good husband, and their wives used to weave fabrics from gibbon fur-until the last gibbon in their territory was killed (Fan \& Huo, 2009). Similar practices occur throughout Southeast Asia.

This spring, I went at dawn into the Mengla Nature Reserve in Xishuangbanna, where the Aini used to hunt gibbons, and listened in vain for the gibbon songs that used to ring out over the misty mountains each morning.

Although I am sympathetic to the need for ethnic minorities to hunt wildlife for cultural as well as nutritional reasons - as do the Aboriginal peoples of Canada - there has to be a reasonable limit to the point where it does not threaten species with extinction. I have no such sympathy for rich people who buy endangered species as food, fur or medicine simply to flaunt their wealth.

Wildlife in the remote mountains of the region is so little known that species are still being discovered. In 2010, biologists announced the discovery of a new species of snub-nosed monkey in Myanmar, along with the assessment that is it critically imperiled by poaching for trade into China. The same year, a new species of gibbon, the northern buff-cheeked gibbon, was described from mountains along the border between Vietnam and Laos; although its conservation status has not been officially determined, it will no doubt be assessed as critically imperiled. It is disconcerting to think that some species, even of higher primates (gibbons are apes, in the Human family line), may go extinct before being discovered.

Every five years, the journal, Primate Conservation, publishes a list of the 25 most endangered primates. The Hainan crested gibbon, with fewer than 20 individuals remaining, is not on the 2010 
list. This is because it was taken off the previous (2006) list to make room for the eastern black crested gibbon, which had been thought extinct until a few individuals were found clinging to forest remnants high in the mountains along the Vietnam-China border. What is the state of wildlife conservation when a hominoid species down to fewer than two dozen individuals is not on the list of Earth's most endangered primates?

Since I began studying gibbons in 2007, two gibbon species, the white-handed and white-cheeked, have been extirpated from China (Fan \& Huo, 2009; Grueter et al., 2009). The eastern hoolock gibbon, numbering perhaps a hundred individuals near the Myanmar border, may not be far behind. It is a big loss. Since pre-Song Dynasty at least - for more than 2000 years - gibbons have been an important icon in Chinese cultures. Gibbons are, as a traveler to China noted in 1967, "a symbol of the unworldly ideals of the poet and the philosopher, and of the mysterious link between man and nature." Partly because of their marital fidelity - gibbons mate for life and live in nuclear families like humans - and the loud, eerie duets that the mated pairs sing every morning, gibbons have inspired poetry in China for millennia. They are portrayed in paintings and in ceramic and other sculptures. Gibbons are also used in Daoist and Buddhist symbology that originated in China and later spread to Japan and Korea, even though gibbons have never occurred there naturally.

While trekking in search of rare primates in a large national park in Vietnam in 2007, I found that the gibbon calls, which used to ring out from the forest each morning, can now be heard only from a few caged animals confiscated from poachers (Harding, 2012). Indeed, each of the six species of gibbon that occurs in Vietnam is critically endangered and all are still under severe illegal hunting pressure. In a different protected area, I was fortunate to see Delacour's langur, an endemic species of leaf monkey. Fewer than 200 remain. When last surveyed, just three populations were found, of which only one is thought to be viable (Harding, 2011). A decade ago, there were 19 known populations. Local people still hunt them, but less now that they see some income from ecotourists like me.

A 1993-1996 survey of illegal wildlife In Guangxi Province found that up to 30 tons per day were smuggled across the border from Vietnam ( $\mathrm{Li} \& \mathrm{Li}, 1998)$. The 55 species included mammals, birds, reptiles and amphibians, of which 19 are listed under CITES, the Convention on International Trade in Endangered Species.

Laws are better now, but enforcement lags behind. Vietnam has a new (2006) wildlife protection law, and it works like this (Nadler et al., 2007): A smuggler catches, say, a gibbon, in a National Park (there aren't many gibbons left outside of national parks and nearly every survey within the parks turns up evidence of poaching). A forestry official catches the poacher and levies a fine. The poacher pays the fine and the official issues a receipt. Now the poacher is allowed to buy the gibbon back from the official and buy an export permit. Everybody is happy: the official has pocketed not only the fine, but the price of the gibbon and the fee for the export permit, and the poacher is now free to take the ape to China with papers proving it is legal. The Chinese trader (no longer a smuggler, since he has a copy of the export permit) may pass a copy of the permit along to the restaurant or apothecary, so their customers are happy, too.

China joined CITES and passed a Wild Animal Protection Law in 1981, which now includes a state protection list known as Animals Under State's Special Protection (ASSP), passed in 1989. All CITES species are on this list. Although China and its neighbours have made considerable progress in enforcement and anti-smuggling campaigns (ARREST, 2013; Lwin, 2011), illegal, rare, and endangered wildlife can still be found in restaurants and apothecaries throughout Guangxi, and there is still a large volume of trade in wildlife products across Yunnan's borders with Myanmar, Laos and Vietnam (Lwin, 2011; O'Connell-Rodwell \& Parry-Jones, 2002). Although better endangered species protection laws and far better enforcement are urgently needed, customs and wildlife agencies clearly can't solve this problem without more extensive government support.

This spring, I visited the Sanchahe Nature Reserve, southern Yunnan near the Lao PDR border, where China's last remaining elephants are a tourist draw. They reminded me of a recent article in The 


\section{EDITORIAL}

Vancouver Sun newspaper, when the reporter in that same valley asked a woman buying jewelry made of ivory if she was aware that the elephants were endangered and that the ivory was illegal in international law. She had no idea. Yet China (including Taiwan and Hong Kong) is by far the biggest destination of illegal ivory, with 176,000 US Tons seized by customs agencies from 1989 to 2011, more than all other countries put together (Christy, 2012).

In Angkor Watt, the ancient Khmer temple complex in Cambodia, on an early morning birding walk I saw mist nets strung among the temples to catch bats, and later saw roasted bats for sale in the market in the nearby town of Siem Rap. My guide told me that netting bats is illegal and the poachers take them down each morning before the wardens arrive.

I don't believe that Southeast and East Asian consumers are any less ethical in their dining, dress and medicine choices that any other culture, but many clearly are not getting the message that these decisions are endangering species. The solution has to include better education of consumers.

\section{Literature Cited}

Alves, R. R. N., W. M. S. Souto and R. R. D. Barboza, 2010. Primates in traditional folk medicine: a world overview. Mammal Review, 40: 155-180.

ARREST, 2013. New campaign against endangered species trade expands to China's highway checkpoints, posted April 10, 2013, ARREST/Conservation International.

Brook, S., P. Van Coeverden de Groot, S. Mahood and B. Long, 2011. Extinction of the Javan Rhinoceros (Rhinoceros sondaicus) from Vietnam, WWF report, WWF Vietnam, WWF-US, Queen's University.

Christy, B., 2012. Blood Ivory, National Geographic, October 2012.

Conway-Smith, E., 2013. Was the last rhino in Mozambique killed?, Global Post, May 1, 2013, http://www.globalpost.com/dispatch/news/science/wildlife-news/130501/rhino-poaching-mozambiquerhinoceros-south-africa.

Fan, P. -F., and S. Huo, 2009. The northern white-cheeked gibbon (Nomascus leucogenys) is on the edge of extinction in China. Gibbon Journal, 5: 44-52.

Goodman, J., 2009, Yunnan: China south of the clouds. Sheung Wan, Hong Kong, Odyssey Books.

Groves, C. P., P. Fernando and J. Robovsky, 2010. The sixth rhino: a taxonomic re-assessment of the critically endangered northern white rhinoceros. PLoS ONE, 5: e9703.

Grueter, C. C., X. Jiang, R. Konrad, P. Fan, Z. Guan and T. Geissmann, 2009. Are Hylobates lar Extirpated from China? International Journal of Primatology, 30: 553-567.

Harding, L. E., 2011. Trachypithecus delacouri (Primates: Cercopithecidae). Mammalian Species, 43: $118-128$.

Harding, L. E., 2012. Nomascus leucogenys. Mammalian Species, 44: 1-15.

Humane Society International, 2013. Rhino poaching, available at http://www.hsi.org/issues/rhinoceros _poaching/.

Hussain, Z., 2013. Drones guard against rhino poaching in India, Agence France Presse/Huffington Pose, April 9, 2013.

Li, Y. and D. Li, 1998. The dynamics of trade in live wildlife across the Guangxi border between China and Vietnam during 1993-1996 and its control strategies. Biodiversity and Conservation, 7: 895-914. 


\section{EDITORIAL}

Lwin, E. E. T., 2011. Illegal wildlife trade on increase: govt, Myanmar Times, mmtimes.com, August 22 $28,2011$.

Meijaard, E. and D. Sheil, 2008. The persistence and conservation of Borneo's mammals in lowland rain forests managed for timber: observations, overviews and opportunities. Ecological Research, 23: 21-34.

Nadler, T., V. N. Thanh and U. Streicher, 2007. Conservation status of Vietnamese primates. Vietnamese Journal of Primatology, 1: 7-26.

Nijman, V., 2005. In full swing: an assessment of trade in orang-utans and gibbons on Java and Bali, Indonesia, Petaling Jaya, Selangor, Malaysia, TRAFFIC Southeast Asia: 59.

Nijman, V. and E. Meijaard, 2008. Zoogeography of primates in insular Southeast Asia: species-area relationships and the effects of taxonomy. Contributions to Zoology, full text available at <http://dpc.uba.uva.nl/ctz/vol77/nr02/art08> 77.

O'Connell-Rodwell, C. and R. Parry-Jones, 2002. An Assessment of China's Management of Trade in Elephants and Elephant Products, Pages 67, TRAFFIC International.

Stop Rhino Poaching Now, 2013. Stop rhino poaching now, available at www.stoprhinopoaching.com/.

Wich, S., E. Meijaard, A. Marshall, S. Husson, M. Ancrenaz, R. Lacy and C. Van Schaik, 2008. Distribution and conservation status of the orang-utan (Pongo spp.) on Borneo and Sumatra: how many remain? Oryx, 42: 329-339.

World Wildlife Fund, 2012. African rhino poaching crisis, available at http://wwf.panda.org/.

World Wildlife Fund Global, 2013. Greater one-horned rhinoceros, accessed 15 May 2013, available at www.wwfpanda.org/.

Lee E. Harding

Sectional Editor: Taprobanica, the journal of Asian Biodiversity

May $25^{\text {th }}, 2013$

SciWrite Environmental Sciences Ltd.

2339 Sumpter Drive

Coquitlam, British Columbia,

Canada 